Article

\title{
Chemical Composition, Fatty Acid Profile, and Lipid Quality Indices in Commercial Ripening of Cow Cheeses from Different Seasons
}

\author{
Beata Paszczyk ${ }^{1, *(\mathbb{D})}$, Magdalena Polak-Śliwińska ${ }^{1}$ (D) and Anna E. Zielak-Steciwko ${ }^{2}$ (D) \\ 1 Department of Commodity and Food Analysis, Faculty of Food Sciences, University of Warmia and Mazury \\ in Olsztyn, 10-726 Olsztyn, Poland; m.polak@uwm.edu.pl \\ 2 Department of Cattle Breeding and Milk Production, Wroclaw University of Environmental and Life, \\ 51-630 Wrocław, Poland; anna.zielak-steciwko@upwr.edu.pl \\ * Correspondence: paszczyk@uwm.edu.pl; Tel.: +48-89-523-36-81
}

check for

updates

Citation: Paszczyk, B.;

Polak-Śliwińska, M.; Zielak-Steciwko, A.E. Chemical Composition, Fatty Acid Profile, and Lipid Quality Indices in Commercial Ripening of Cow Cheeses from Different Seasons. Animals 2022, 12, 198. https:// doi.org/10.3390/ani12020198

Academic Editors: Aneta Brodziak and Joanna Barłowska

Received: 19 November 2021

Accepted: 12 January 2022

Published: 14 January 2022

Publisher's Note: MDPI stays neutral with regard to jurisdictional claims in published maps and institutional affiliations.

Copyright: (C) 2022 by the authors. Licensee MDPI, Basel, Switzerland. This article is an open access article distributed under the terms and conditions of the Creative Commons Attribution (CC BY) license (https:// creativecommons.org/licenses/by/ $4.0 /)$.
Simple Summary: Cheese and other dairy products are important components of the diet that have a positive effect on human health. These products include substantial amounts of important nutrients, including proteins, bioactive peptides, amino acids, fat, fatty acids, and vitamins. The quantitative composition of fatty acids in milk fat changes under the influence of various factors, such as animal feeding, breed, lactation stage, individual characteristics, climatic conditions, health, age, and others. Of the above-mentioned factors, the most important influence is the diet. This work presents chemical composition and fatty acid profile, with particular emphasis on trans isomers (cis9trans11 C18:2 (CLA), $\mathrm{C} 18: 1$ and $\mathrm{C} 18: 2$ isomers) and lipid quality indices in ripening of cow cheeses from different seasons. The first batch contained cheeses produced in winter and purchased from the market between May and June 2020. The second batch contained cheeses produced in summer and purchased from the market between November and December 2020. Results obtained show differences between summer and winter cheeses in their chemical composition, the content of lipid quality indices, and fatty acids.

Abstract: The aim of the study was to compare and demonstrate whether commercial rennet ripening cheeses available on the market in summer and winter differ in their chemical composition, fatty acid profile, content of cis9trans11 C18:2 (CLA) acid and other trans isomers of C18:1 and C18:2 acid and whether they are characterized by different values of lipid quality assessment indices. The experimental material consisted of rennet ripening of cheeses produced from cow's milk available in the Polish market. The first batch contained cheeses produced in winter and purchased from the market between May and June. The second batch contained cheeses produced in summer and purchased between November and December. Chemical composition was analyzed by FoodScan apparatus. The gas chromatography (GC) method was used to determine the content of fatty acids. Results obtained in the presented study indicate that the chemical composition, content of fatty acids trans isomers, and lipid quality indices varied between summer and winter cheeses. The summer cheeses were richer sources of MUFA and PUFA compared to winter cheeses. Summer cheeses were also characterized by lower content of SFA, higher content $n-3$, lower $n-6 / n-3$ ratio, and higher content of DFA. Higher contents of CLA and trans C18:1 and C18:2 were found in summer cheeses.

Keywords: fat; protein; fatty acids; CLA; trans isomers; lipid quality indices; cow cheese

\section{Introduction}

The production of cheese and cottage cheese is the oldest milk processing method mastered by man and is the foundation for the development of the modern dairy industry. The cheese production in Poland increased over the last decade and was accompanied by an enlargement of cheese variety. Polish cheese producers have introduced many new types of cheese to the market that have not been manufactured in the country so far, which 
clearly shows changes in consumption patterns and consumer preferences [1,2]. In Poland, 3134.4 million liters of drinking milk were produced between January and November 2020, which was $6.9 \%$ more than in the same period of 2019. However, during the 11 months of $2020,310.1$ thousand tons of rennet ripened cheese were produced, which was $2.6 \%$ less than in 2019 [3]. The nutritional value of cheeses depends mostly on milk characteristics and the production technology. The technological parameters used in cheese production determine the unique and distinct nutritional properties of each cheese type. Substantial amounts of important nutrients, including proteins, bioactive peptides, amino acids, fat, fatty acids, vitamins, and minerals can be found in cheeses [4]. Milk fat is considered to be the most complex fat in the human diet as there are more than 400 distinct fatty acids (FA) [5]. SFAs are the predominant class of fatty acids in milk fat. This group of fatty acids includes: short-chain fatty acids (SCFA), medium and long-chain fatty acids, as well as odd fatty acids (OCFA) and branched-chain fatty acids (BCFA, iso- and anteiso) [5,6]. Dietary fatty acids may have different effects on human health $[7,8]$. Saturated fatty acids (SFA), mainly lauric (C12:0), myristic (C14:0), and palmitic (C16:0) acids, may show adverse effects [9-11]. Branched-chain fatty acids have anti-tumor effects and improve pancreatic $\beta$-cell function $[12,13]$. BCFA originate from the cell membranes of rumen bacteria that dairy and meat products from ruminants contain and those acids are a unique source of these fatty acids [14]. Monounsaturated fatty acids (MUFA) and polyunsaturated fatty acids (PUFA) are biologically beneficial to human health $[10,15]$. The best source of natural trans fatty acids, such as: vaccenic acid (trans11 C18:1, VA) and conjugated linoleic acid (cis9trans11 C18:2; CLA) in milk fat, which exhibit favorable properties compared to artificial trans fatty acids in partially hydrogenated oils [16]. Trans11 acid has anti-tumor and antiatherosclerotic effects [17]. According to literature data [18-22] cis9trans11 C18:2 acid has a number of health-promoting properties, including anti-carcinogenic, antiatherosclerotic, antioxidant and anti-inflammatory effects. Anti-cancer and anti-atherosclerotic properties are attributed to $\operatorname{cis} 9 \mathrm{C} 18: 1$ acid and cis 9 cis $12 \operatorname{cis} 15 \mathrm{C} 18: 3$ acid [10,23]. $n-3$ PUFAs prevent heart disease and improve the immune response. The consumption of $n-6$ and $n-3$ acids has a positive effect on human health [15]. Milk fat is also a rich source of butyric acid (C4:0), which has beneficial effects on the gastrointestinal tract and supports treatments of chronic diseases of the gastrointestinal tract associated with inflammation [24,25].

The quantitative composition of fatty acids in milk fat changes under the influence of various factors, such as: animal feeding, breed, lactation stage, individual characteristics, climatic conditions, health, age, and others [26-30]. Of the factors mentioned, animal feeding has the greatest influence, which includes pasture feeding, consumption of grass, hay, or silage [31-38]. Fat from milk obtained in the green feed season contains much more C18 acids, mainly C18:1 acid, and much less palmitic and myristic acid than the one obtained in the cowshed feeding season [39,40]. Milk fat from the pasture period of cow's feeding is also characterized by a higher content of cis 9 trans 11 C18:2 conjugated linoleic acid and C18:1 and C18:2 trans isomers [30,34,38]. A study conducted by Żegarska et al. [38] indicated that the proportion of cis 9 trans $11 \mathrm{C} 18: 2$ acid in fat from the winter period ranged between $0.32 \%$ to $0.52 \%$ of the total fatty acids composition, whereas in fat from the summer period, it was from $1.06 \%$ to $1.76 \%$. The chemical composition and fatty acid composition of cheese may differ from that of milk. Cheese composition depends on the milk's microbiological and chemical composition, the cheesemaking technology, ripening time, and cheese factory conditions [41-43]. Since milk fat and protein are main constituents of cheese, product quality is heavily influenced by their concentrations in milk. The main component determining the quality of milk used for cheese production is the protein content. Milk high in protein, especially casein, results in high yield and good quality cheese products. The fat content is important as well, but especially the ratio of protein or casein content to it is of significance. The quality of cheese, its caloric and nutritional value, physical properties, and chemical composition depends, to a large extent, on the fat content. The fat content in milk can vary within wide limits, from $2.5 \%$ to $5 \%$ or sometimes even more. The content of protein in the milk varies to a lesser extent in comparison to milk fat 
content. The biggest fraction within protein content is covered by casein, with is about 3\% of all proteins found in milk [44]. Changes in the concentrations of protein and fat in milk significantly influence the composition of the cheese and its yield. Milk protein and fat contents vary greatly according to species, breed, season, health status, stage of lactation, and animal diet $[10,33,45]$. The type of starter culture used might modify the total content of protein, fat, ash, and fatty acids profile of the cheese, due to the different activity and specificity of proteolytic and lipolytic enzymes [46]. Because of dehydration, protein and fat contents increase during ripening time [4,46,47]. According to literature data [48-53], the profile of fatty acids, including the content of CLA in cheeses and fermented drinks, may be influenced by the conditions used in technological processes, the additives used, the activity of the added starter cultures, and ripening time. Rutkowska et al. [54], Zeppa et al. [55], and Serrapica et al. [56] demonstrated that cheeses from summer season had higher unsaturated fatty acids (UFA) content and lower content of saturated fatty acids (SFA) compared to cheeses from winter season.

The aim of the study was to compare and demonstrate whether commercial rennet ripening of cheeses available on the market in summer and winter differ in their chemical composition, fatty acid profile, content of cis9trans11 C18:2 (CLA) acid, and other trans isomers of C18:1 and C18:2 acid and whether they are characterized by different values of lipid quality assessment indices.

\section{Materials and Methods}

\subsection{Cheeses Samples}

To make cheese, you need milk, rennet, microorganisms, and salt. The main stages of the technological process of producing rennet ripened cheeses are: pasteurization and normalization of milk, addition of leaven from pure cultures and calcium chloride, mixing and heating, rennet addition, coagulation and cutting, shaping and pressing of cheese, salting in brine, dripping, and maturation [57]. The quantitative and qualitative diversification of individual ingredients, followed by modifications to the stages of the production process, have led to the development of many types of cheese. Commercial rennet ripened cheeses (Gouda, Edamski, Morski, Edam, Kasztelański, Podlaski) produced from cow's milk available in the Polish market were used as experimental material. Taking into account the cheese production process, including the ripening time and the shelf-life specified by the manufacturer on the packaging, the analyzed cheeses were divided into two batches. The first batch (labeled as winter cheeses; $n=20$ ) contained cheeses produced in winter and purchased from the market between May and June 2020. The second batch, the same cheeses from the same producers (labeled as summer cheeses; $n=20$ ), contained cheeses produced in summer and purchased from the market between November and December 2020. The products were bought from stores in Olsztyn, Poland. All samples were analyzed in duplicate.

\subsection{Analytical Methods}

\subsubsection{Chemical Composition}

Concentration of fat, protein, water and dry matter in cheese samples were analyzed by FoodScan apparatus (Foss, Hilleroed, Denmark).

\subsubsection{Lipid Extraction}

Folch's method was used for fat extraction from cheeses [58].

\subsubsection{Preparation of Fatty Acid Methyl Esters}

Methyl esters were prepared using the IDF method (ISO 15884:2002) [59]. To each fat sample, N-hexane and $2 \mathrm{M} \mathrm{KOH}$ in methanol were added and the mixtures were shaken. In the next step, sodium hydrogen sulphate $\left(\mathrm{NaHSO}_{4}\right)$ was added and the mixtures were centrifuged $\left(3000 \mathrm{~min}^{-1}\right)$. The top layer of the prepared methyl esters was collected for chromatographic analysis. 


\subsubsection{Gas Chromatography (GC) Analysis}

The methyl esters were analyzed by the GC method. Chromatographic separation was performed using Hewlett Packard 6890 gas chromatography (Münster, Germany) with a flame ionization detector (FID) and $100 \mathrm{~m}$ capillary column (Chrompack, Middelburg, The Netherlands) and internal diameter $0.25 \mathrm{~mm}$. The liquid phase was CP Sil 88 and film thickness was $0.20 \mu \mathrm{m}$. The analysis was carried out in the following conditions: column temperature from $60^{\circ} \mathrm{C}$ (for $1 \mathrm{~min}$ ) to $180^{\circ} \mathrm{C}\left(\Delta \mathrm{t}=5^{\circ} \mathrm{C} / \mathrm{min}\right.$ ), detector temperature $250^{\circ} \mathrm{C}$, injector temperature was $225^{\circ} \mathrm{C}$, helium was carrier gas (gas flow $1.5 \mathrm{~mL} / \mathrm{min}$ ). Sample injection volume was $0.4 \mu \mathrm{L}$ (split mode 50:1). Identification of fatty acids was carried out based on the comparison of their retention time with the retention time of methyl esters of fatty acids of reference milk fat (BCR Reference Materials) of CRM 164 symbol and literature data [60-63]. The positional trans isomers of C18:1 were identified using the standards of methyl esters for these isomers (Sigma-Aldrich, St. Louis, MO, USA and Supelco, Bellefonte, PA, USA). The ratio of their peak area to the total area of all identified acids (\% mass fraction) helped with calculations of the proportions of the individual acids.

\subsubsection{The Lipid Quality Indices}

The following formulas were used to determine Lipid Quality Indices on the basis of fatty acid composition:

Index of Atherogenicity (AI)—according to Ulbricht and Southgate [11] and Osmari et al. [64]:

$$
\mathrm{AI}=(\mathrm{C} 12: 0+(4 \times \mathrm{C} 14: 0)+\mathrm{C} 16: 0) /(n-3 \text { PUFA }+n-6 \text { PUFA }+ \text { MUFA })
$$

Index of Thrombogenicity (TI)—according to Ulbricht and Southgate [11] and Osmari et al. [64]:

$$
\begin{gathered}
\mathrm{TI}=(\mathrm{C} 14: 0+\mathrm{C} 16: 0+\mathrm{C} 18: 0) /((0.5 \times \mathrm{C} 18: 1)+(0.5 \times \text { sum of other MUFA }) \\
\quad+0.5 \times n-6 \text { PUFA })+(3 \times n-3 \text { PUFA })+n-3 \text { PUFA } / n-6 \text { PUFA }))
\end{gathered}
$$

Hypocholesterolaemic fatty acids (DFA)—according to Medeiros et al. [65]:

$$
\mathrm{DFA}=\mathrm{UFA}+\mathrm{C} 18: 0
$$

Hypercholesterolaemic fatty acids (OFA):

$$
\mathrm{OFA}=\mathrm{C} 12: 0+\mathrm{C} 14: 0+\mathrm{C} 16: 0
$$

Hypocholesterolaemic/hypercholesterolaemic ratio $(\mathrm{HH})$-according to Ivanova and Hadzhinikolova [66]:

$$
\mathrm{H} / \mathrm{H}=(\mathrm{C} 18: 1 n-9+\mathrm{C} 18: 2 n-6+\mathrm{C} 18: 3 n-3) /(\mathrm{C} 12: 0+\mathrm{C} 14: 0+\mathrm{C} 16: 0)
$$

2.2.6. Assessment of the Coverage of Daily Requirements for Selected Nutrients According to National Nutrition Standards

Based on per capita cheese intake data compiled by the CSO in 2019 and data on fat intake estimated based on the Reference Intake Value (RI) and protein intake based on the recommended Recommended Daily Allowance (RDA) intake for selected population groups presented in the Nutrition Standards for the Polish population by the Institute of Food and Nutrition, the \% coverage of the daily requirement for these nutrients was calculated $[67,68]$.

\subsection{Statistical Analysis}

STATISTICA ver. 13.1 software (Statsoft, Kraków, Poland) was applied to perform the statistical analysis [69]. One-way analysis of variance (ANOVA) with the Duncan's test was 
used to find means that were significantly different from each other. Statistically significant differences were accepted at $p<0.05$.

\section{Results and Discussion}

\subsection{Chemical Composition}

The mean content of fat and water for summer and winter cheeses was observed at a similar level (Figure 1). Winter cheeses were characterized by significantly higher $(p<0.05)$ content of protein than summer cheeses. The composition and quality of cheese are influenced by various factors: the microbiological and chemical composition of milk, the technology of cheese making, the time and conditions of maturation [70-72]. Milk protein and fat content can vary due to different species, breed, season, health status, stage of lactation, and animal diet $[4,47,73]$. In addition, the type of starter culture used in cheese manufacture might modify the total content of protein, fat, ash, and fatty acids profile due to different activity and specificity of proteolytic and lipolytic enzymes $[46,74]$. The protein and fat content increase during ripening time, which can be caused by partial evaporation of water $[4,46]$.

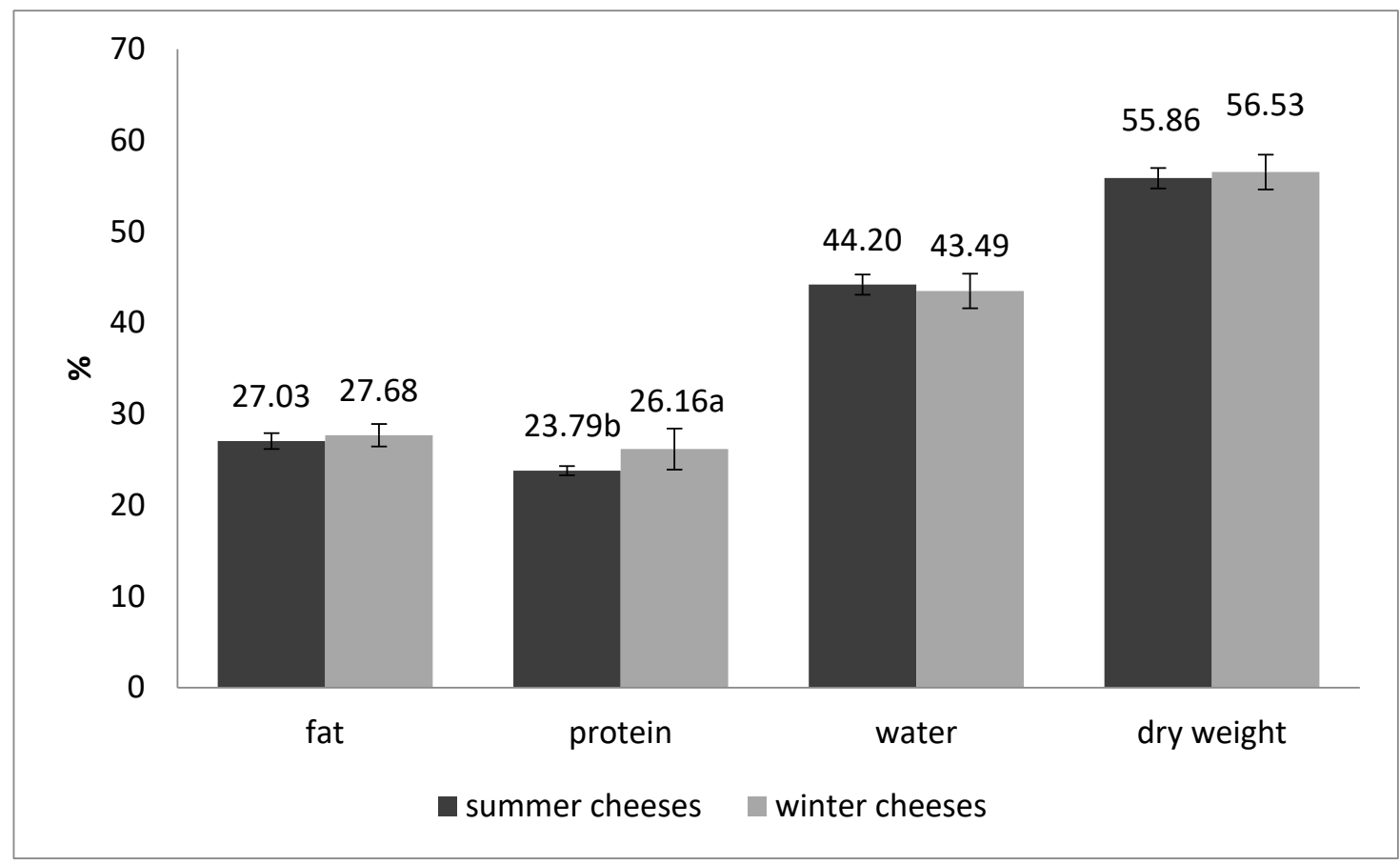

Figure 1. The chemical composition (\%) of summer and winter cheeses made from cow's milk. $\mathrm{a}, \mathrm{b}$-values differ significantly between groups $(p<0.05)$.

Protein is an essential macronutrient in the human diet. It is recognised as a key dietary component of human body's requirements considering its complex metabolic transformations [67]. This is due to the fact that protein metabolism is determined by many factors. Proteins are necessary structural and functional components of every cell in the human body, undergoing energy metabolism as well as intensive interactions with other nutrients that are supplied with food. Moreover, these molecules are essential for the development and growth processes of young organisms, also acting as regulators of gene expression [67]. Proteins are important nutrient because they provide protein nitrogen and specific types of amino acids [67]. Natural sources of proteins and amino acids are raw materials or food products, of which animal products such as dairy (milk, cheese, eggs) and meat, including fish and poultry (except connective tissue proteins low in tryptophan), are complete sources of protein. The main factors influencing human protein requirements are body energy balance, physiological status, age, health status, body weight, physical 
activity [67,75-77]. In the 2017 Nutrition Standards for the Polish population [46], reference intake ranges (RI) were defined for fat and carbohydrates. In contrast, standards for protein and other nutrients were set at levels of average intake EAR and recommended intake RDA, or adequate intake AI. The RDA is the level of nutrient intake that covers the needs of almost all people in a given group. The reference intake (reference macronutrient intake ranges, $\mathrm{RI}$ ) is the level of macronutrient intake expressed as a percentage of energy requirements. It indicates what range of the percentage of energy from a given macronutrient ensures the maintenance of good health and is associated with a low risk of developing selected chronic diseases [67]. The RDA level (representing the needs of 97-98\% of the population, calculated as EAR + 2SD) is intended for intake planning or population-level nutritional goal planning. The recommended daily allowance (RDA) for protein is the amount, based on nitrogen balance (physiological), needed to meet basic nutritional (vital) needs for this component. For adults, it is $0.9 \mathrm{~g} / \mathrm{kg}$ body weight/day; however, people over 65 years of age are currently advised to consume at least $1 \mathrm{~g} / \mathrm{kg}$ body weight of protein and to increase their intake in the presence of symptoms of malnutrition or chronic disease to at least $1.2 \mathrm{~g} / \mathrm{kg}$ body weight (and in justified cases of disease even to $1.5 \mathrm{~g} / \mathrm{kg}$ body weight/day).

For people with increased physical activity, athletes, an intake of $1.4-2 \mathrm{~g} / \mathrm{kg}$ body weight/day is recommended. In a sense, this is the minimum amount that needs to be consumed each day in order to keep the body's immunity at the right level and not get sick. It is assumed that the average of 7 or 10 days, should be within the range of the established daily norm. The correct fulfilment of a person's protein requirements does not consist of consuming the required amount of protein each day. The average protein intake should not be less than the level of the EAR standard or the lower limit of \% energy from protein, which means that it will then be in accordance with the recommendations of Jarosz et al. [67]. In Poland in 2019, the monthly consumption of cheese per urban resident was $1.0 \mathrm{~kg}$, while per rural resident, it was $0.8 \mathrm{~kg}$ [68]. Taking into account the data on cheese consumption per capita compiled by the CSO in 2019 and the protein intake data based on the recommended RDA intake for selected population groups presented in the Nutrition Standards for the Polish population by the Institute of Food and Nutrition and the results of protein determinations in the studied cheese samples, the \% coverage of the daily requirement for this component was calculated. It was found that the indicated level of intake covered the recommended protein intake in $15.56 \%$ for women over 19 years of age and in $13.33 \%$ for men over 19 years of age when consuming winter cheeses (Table 1) and in $14.44 \%$ for women over 19 years of age and in $12.22 \%$ for men over 19 years of age when consuming summer cheeses, whereas for pregnant and lactating women from $8.97 \%$ to $10.83 \%$ and from $9.66 \%$ to $11.67 \%$, respectively.

Table 1. Covering the daily protein requirements after eating a portion of cheese.

\begin{tabular}{|c|c|c|c|c|c|c|}
\hline \multirow{2}{*}{ Group/Age } & \multirow{2}{*}{$\begin{array}{c}\text { Body Weight } \\
{[\mathrm{kg}]}\end{array}$} & \multirow{2}{*}{$\begin{array}{c}\text { Reference Protein } \\
\text { [g/kg b.w./Day] }\end{array}$} & \multirow{2}{*}{$\begin{array}{c}\text { National Food Ration } \\
\text { Protein -RDA } \\
\text { [g/kg b.w./Day] }\end{array}$} & \multirow{2}{*}{$\begin{array}{c}\text { Cheese } \\
\text { Consumption per Capita in } \\
2019 * \text { [kg Cheese/Day }]\end{array}$} & \multicolumn{2}{|c|}{$\begin{array}{c}\text { DDC } \\
{[\%]}\end{array}$} \\
\hline & & & & & $\begin{array}{l}\text { Summer } \\
\text { Cheeses }\end{array}$ & $\begin{array}{l}\text { Winter } \\
\text { Cheeses }\end{array}$ \\
\hline Women $\geq 19$ & $45-75$ & 0.80 & 0.90 & & 14.44 & 15.56 \\
\hline Men $\geq 19$ & $55-85$ & 0.80 & 0.90 & & 12.22 & 13.33 \\
\hline $\begin{array}{c}\text { Pregnat } \\
\text { women }<19 \text { age }\end{array}$ & $45-75$ & 1.10 & 1.20 & 0.033 & 10.83 & 11.67 \\
\hline $\begin{array}{c}\text { Pregnat } \\
\text { women } \geq 19 \text { age }\end{array}$ & $45-75$ & 1.10 & 1.20 & & 10.83 & 11.67 \\
\hline $\begin{array}{l}\text { Breast-feeding } \\
\text { women < } 19 \text { age }\end{array}$ & $45-75$ & 1.3 & 1.45 & & 8.97 & 9.66 \\
\hline $\begin{array}{c}\text { Breastfeeding } \\
\text { women } \geq 19 \text { age }\end{array}$ & $45-75$ & 1.3 & 1.45 & & 8,97 & 9.66 \\
\hline
\end{tabular}

* Data in accordance with the Central Statistical Office in Poland in 2019 [68]. Source: own study based on Jarosz et al. [67]; Abbreviations: RDA-Recommended Daily Allowance; DDC-Daily Demandes Coverage. 
Table 2 shows the estimated fat intake per capita in Poland based on cheese consumption data in 2019 [54]. Fat intake was estimated based on the Reference Intake (RI) presented in the Nutrition Standards for the Polish Population by the Food and Nutrition Institute [67]. The fat intake standards were developed based on the recommendations of Polish scientific societies and updated opinions of EFSA and FAO/WHO [67]. In developing the standards, the assumption was made that $9 \mathrm{kcal}$ corresponds to one gram of fat [78]. Considering the physiological functions of fats, their insufficient dietary supply may lead to an increased risk of deficiency of fat-soluble vitamins (A, D, E, K), especially among vegetarians [79,80] and central nervous system (CNS) dysfunction, since fat is an important component of this system (including the brain) and fatty acids are the most key components of this organ. Considering the reference intake value (RI), the cheeses studied can be an important source of fat in the daily diet. Data on dietary intake of cheeses in the population in Poland may cover up to about $12 \%$ of the reference intake value for fat in the group of women over 19 years of age, while in the group of men with a higher fat requirement, from 7.76 to $8.53 \%$ of the RI. In the diets of pregnant and lactating women, whose fat requirements are significant, cheeses provide varying degrees of RI coverage from $9.50 \%$ to $11.15 \%$ for summer cheeses and from $9.71 \%$ to $11.41 \%$ for winter cheeses.

Table 2. Covering the daily fat requirements after eating a portion of cheese.

\begin{tabular}{|c|c|c|c|c|c|c|}
\hline \multirow{2}{*}{\multicolumn{2}{|c|}{ Group/Age }} & \multirow{2}{*}{$\begin{array}{c}\text { Body } \\
\text { Weight }[\mathrm{kg}]\end{array}$} & \multirow{2}{*}{$\begin{array}{c}\text { RI } \\
{[\text { g/Person/Day] }}\end{array}$} & \multirow{2}{*}{$\begin{array}{c}\text { Cheese } \\
\text { Consumption per capita in } 2019 * \\
{[\mathrm{~kg} \text { Cheese/Day }]}\end{array}$} & \multicolumn{2}{|c|}{$\begin{array}{c}\text { DDC } \\
{[\%]}\end{array}$} \\
\hline & & & & & $\begin{array}{l}\text { Summer } \\
\text { Cheeses }\end{array}$ & $\begin{array}{l}\text { Winter } \\
\text { Cheeses }\end{array}$ \\
\hline \multirow{2}{*}{\multicolumn{2}{|c|}{ Women $\geq 19$}} & & 77 & \multirow{8}{*}{0.033} & 11.58 & 11.86 \\
\hline & & 55 & 85 & & 10.49 & 10.74 \\
\hline \multirow{2}{*}{\multicolumn{2}{|c|}{ Men $\geq 19$}} & 65 & 107 & & 8.34 & 8.53 \\
\hline & & & 115 & & 7.76 & 7.94 \\
\hline \multirow{3}{*}{$\begin{array}{l}\text { Pregnat } \\
\text { women }\end{array}$} & I & & 80 & & 11.15 & 11.41 \\
\hline & II & 65 & 87 & & 10.25 & 10.49 \\
\hline & III & & 93 & & 9.60 & 9.82 \\
\hline Breastfe & omen & 85 & 94 & & 9.49 & 9.71 \\
\hline
\end{tabular}

${ }^{*}$ Data in accordance with the Central Statistical Office in Poland in 2019 [68]. Source: own study based on Jarosz et al. [67]; Abbreviations: RI—Reference Intake; DDC—Daily Demandes Coverage.

\subsection{Fatty Acids Profile and Lipid Quality Indices in Cheese Fat}

In the presented study, saturated fatty acids (SFA) predominated in all examined cheeses. A significantly lower $(p<0.05)$ content of these acids $(58.61 \pm 1.12 \%)$ was found in cheeses from the summer period than in these from the winter period $(62.30 \pm 0.84 \%)$. In addition, all cheese samples contained major SFA in the form of palmitic acid, myristic acid, and stearic acid (Table 3).

Furthermore, monounsaturated fatty acids (MUFA) and polyunsaturated fatty acids (PUFA) content was significantly higher $(p<0.05)$ in summer than winter cheeses (Table 4$)$. In both groups, oleic acid (cis9 C18:1) was the major MUFA (Table 3). Whereas linoleic acid (C18:2) and linolenic acid (C18:3) were found to be the major PUFA (Table 3). Short-chain fatty acids (SCFA) content did not differ significantly between summer and winter cheeses (Table 4). The summer cheeses had significantly higher $(p<0.05)$ contents of branched-chain fatty acids (BCFA) compared to winter cheeses. The contents of odd-chain fatty acids (OCFA) in the analyzed cheeses were at a similar level (Table 4). Research conducted by Prandini et al. [81] on cheeses made from cow's milk indicated that SFA content ranged from $65.23 \%$ to $68.52 \%$, MUFA content varied from $27.90 \%$ to $31.19 \%$, and PUFA content ranged from $3.48 \%$ to $4.17 \%$. Similar results were obtained by Paszczyk and Łuczyńska [82], who demonstrated that content of MUFA and PUFA in commercial cheeses, made from cow's milk, purchased from September to December was $27.92 \%$ and $3.31 \%$, respectively. 
Table 3. Mean \pm SD and range of fatty acids composition (\% of total fatty acids) in summer and winter cheeses made from cow's milk.

\begin{tabular}{|c|c|c|c|c|c|c|}
\hline \multicolumn{4}{|c|}{ Summer Cheeses } & \multicolumn{3}{|c|}{ Winter Cheeses } \\
\hline \multicolumn{3}{|c|}{ Mean \pm SD } & \multirow[t]{2}{*}{ Min-Max } & \multicolumn{2}{|c|}{ Mean \pm SD } & \multirow[t]{2}{*}{ Min-Max } \\
\hline$n$ & & 20 & & & 2 & \\
\hline C4:0 & 3.05 & \pm 0.36 & $2.56-3.80$ & 2.80 & \pm 0.36 & $2.09-3.25$ \\
\hline C6:0 & 2.12 & \pm 0.08 & $2.00-2.25$ & 1.98 & \pm 0.27 & $1.54-2.25$ \\
\hline $\mathrm{C} 8: 0$ & 1.35 & \pm 0.06 & $1.24-1.44$ & 1.33 & \pm 0.06 & $1.25-1.41$ \\
\hline C10:0 & 3.07 & \pm 0.17 & $2.81-3.29$ & 3.18 & \pm 0.08 & $3.09-3.32$ \\
\hline C10:1 & 0.33 & \pm 0.02 & $0.30-0.36$ & 0.33 & \pm 0.01 & $0.31-0.34$ \\
\hline C11:0 & 0.06 & \pm 0.01 & $0.04-0.07$ & 0.06 & \pm 0.01 & $0.5-0.07$ \\
\hline $\mathrm{C} 12: 0$ & 3.55 & $\pm 0.16^{\mathrm{b}}$ & $3.22-3.69$ & 3.75 & $\pm 0.13^{\mathrm{a}}$ & $3.50-3.88$ \\
\hline C12:1 & 0.08 & \pm 0.01 & $0.07-0.09$ & 0.09 & \pm 0.00 & $0.08-0.09$ \\
\hline $\mathrm{C} 13: 0$ iso & 0.10 & \pm 0.01 & $0.09-0.11$ & 0.10 & \pm 0.01 & $0.09-0.11$ \\
\hline C13:0 & 0.13 & \pm 0.02 & $0.10-0.17$ & 0.12 & \pm 0.01 & $0.10-0.14$ \\
\hline $\mathrm{C} 14: 0$ iso & 0.13 & \pm 0.01 & $0.11-0.14$ & 0.13 & \pm 0.01 & $0.12-0.15$ \\
\hline C14:0 & 11.31 & $\pm 0.24^{\mathrm{b}}$ & $11.18-11.85$ & 12.10 & $\pm 0.23^{\mathrm{a}}$ & $11.66-12.45$ \\
\hline $\mathrm{C} 15: 0$ iso & 0.28 & \pm 0.02 & $0.23-0.31$ & 0.26 & \pm 0.02 & $0.23-0.29$ \\
\hline $\mathrm{C} 15: 0$ aiso & 0.56 & $\pm 0.06^{\mathrm{a}}$ & $0.48-0.63$ & 0.51 & $\pm 0.02^{\mathrm{b}}$ & $0.49-0.53$ \\
\hline C14:1 & 1.03 & \pm 0.13 & $0.85-1.16$ & 1.09 & \pm 0.04 & $1.02-1.12$ \\
\hline $\mathrm{C} 15: 0$ & 1.26 & \pm 0.06 & $1.18-1.34$ & 1.22 & \pm 0.04 & $1.17-1.27$ \\
\hline $\mathrm{C} 16: 0$ iso & 0.31 & \pm 0.03 & $0.28-0.36$ & 0.31 & \pm 0.03 & $0.26-0.34$ \\
\hline C16:0 & 29.09 & $\pm 1.77^{\mathrm{b}}$ & $26.90-31.75$ & 32.53 & $\pm 0.40^{\mathrm{a}}$ & $32.22-32.64$ \\
\hline $\mathrm{C} 17: 0$ iso & 0.44 & $\pm 0.04^{\mathrm{a}}$ & $0.36-0.49$ & 0.36 & $\pm 0.02^{\mathrm{b}}$ & $0.33-0.39$ \\
\hline C17:0 aiso & 0.23 & $\pm 0.03^{\mathrm{a}}$ & $0.19-0.26$ & 0.18 & $\pm 0.00^{\mathrm{b}}$ & $0.17-0.19$ \\
\hline $\mathrm{C} 16: 1$ & 1.65 & \pm 0.25 & $1.24-2.02$ & 1.65 & \pm 0.13 & $1.57-1.97$ \\
\hline C17:0 & 0.86 & $\pm 0.38^{\mathrm{a}}$ & $0.68-1.92$ & 0.72 & $\pm 0.01^{\mathrm{b}}$ & $0.71-0.74$ \\
\hline C17:1 & 0.25 & \pm 0.02 & $0.23-0.29$ & 0.25 & \pm 0.01 & $0.24-0.26$ \\
\hline C18:0 & 9.95 & \pm 0.53 & $9.20-10.72$ & 9.64 & \pm 0.48 & 8.89-10.26 \\
\hline$t 6-t 9 C 18: 1$ & 0.44 & \pm 0.04 & $0.41-0.52$ & 0.42 & \pm 0.02 & $0.37-0.34$ \\
\hline$t 10+t 11 \mathrm{C} 18: 1$ & 2.20 & $\pm 0.65^{\mathrm{a}}$ & $1.27-3.05$ & 1.24 & $\pm 0.09 \mathrm{~b}$ & $1.13-1.35$ \\
\hline t12 C18:1 & 0.30 & \pm 0.04 & $0.26-0.38$ & 0.28 & \pm 0.02 & $0.24-0.30$ \\
\hline c9 C18:1 & 19.59 & $\pm 0.57^{\mathrm{a}}$ & $18.83-20.60$ & 19.04 & $\pm 0.43^{\mathrm{b}}$ & $18.54-19.70$ \\
\hline c11 C18:1 & 0.61 & \pm 0.03 & $0.57-0.67$ & 0.61 & \pm 0.04 & $0.56-0.64$ \\
\hline c12 C18:1 & 0.24 & $\pm 0.04^{\mathrm{b}}$ & $0.19-0.30$ & 0.27 & $\pm 0.03^{\mathrm{a}}$ & $0.21-0.33$ \\
\hline c13 C18:1 & 0.09 & \pm 0.01 & $0.07-0.10$ & 0.09 & \pm 0.01 & $0.07-0.10$ \\
\hline t16 C18:1 & 0.34 & $\pm 0.05^{\mathrm{a}}$ & $0.27-0.42$ & 0.29 & $\pm 0.02^{\mathrm{b}}$ & $0.25-0.31$ \\
\hline C19:0 & 0.19 & $\pm 0.02^{\mathrm{a}}$ & $0.14-0.23$ & 0.16 & $\pm 0.02^{\mathrm{b}}$ & $0.14-0.18$ \\
\hline c9 t13 C18:2 & 0.20 & $\pm 0.03^{\mathrm{a}}$ & $0.15-0.25$ & 0.16 & $\pm 0.01^{\mathrm{b}}$ & $0.15-0.17$ \\
\hline c9 t12 C18:2 & 0.18 & $\pm 0.03^{\mathrm{a}}$ & $0.14-0.22$ & 0.15 & $\pm 0.01^{\mathrm{b}}$ & $0.13-0.17$ \\
\hline$t 11$ c15 C18:2 & 0.26 & $\pm 0.10^{\mathrm{a}}$ & $0.10-0.37$ & 0.10 & $\pm 0.02^{\mathrm{b}}$ & $0.06-0.14$ \\
\hline c9 c12 C18:2 & 1.52 & $\pm 0.19^{\mathrm{a}}$ & $1.28-1.78$ & 1.54 & $\pm 0.14^{\mathrm{a}}$ & $1.39-1.86$ \\
\hline C20:0 & 0.15 & \pm 0.01 & $0.14-0.16$ & 0.15 & \pm 0.01 & $0.13-0.16$ \\
\hline C20:1 & 0.11 & \pm 0.01 & $0.10-0.12$ & 0.11 & \pm 0.00 & $0.11-0.12$ \\
\hline$c 9 c 12 c 15 \mathrm{C} 18: 3$ & 0.53 & $\pm 0.13^{\mathrm{a}}$ & $0.31-0.66$ & 0.35 & $\pm 0.07^{\mathrm{b}}$ & $0.26-0.48$ \\
\hline c9t11 C18:2 (CLA) & 0.88 & $\pm 0.19^{\mathrm{a}}$ & $0.51-1.12$ & 0.44 & $\pm 0.03^{\mathrm{b}}$ & $0.39-0.48$ \\
\hline
\end{tabular}

$n$-number of samples, Min-minimum value, Max-maximum value, Mean-mean value, SD—standard deviation, $\mathrm{a}, \mathrm{b}$ - statistically significant differences $(p<0.05)$. 
Table 4. Mean \pm SD of sum of fatty acids (\% of total fatty acids) and nutritional indices in summer and winter cheeses made from cow's milk.

\begin{tabular}{|c|c|c|c|c|}
\hline \multirow{3}{*}{$\frac{\text { Fatty Acids }}{n}$} & \multicolumn{2}{|c|}{ Summer Cheeses } & \multicolumn{2}{|c|}{ Winter Cheeses } \\
\hline & \multicolumn{2}{|c|}{20} & \multicolumn{2}{|c|}{20} \\
\hline & Mean \pm SD & Min-Max & Mean \pm SD & Min-Max \\
\hline$\Sigma$ SCFA $^{1}$ & $9.58 \pm 0.38$ & $9.10-10.19$ & $9.29 \pm 0.69$ & $8.08-10.07$ \\
\hline$\Sigma \mathrm{BCFA}^{2}$ & $2.08 \pm 0.18^{a}$ & $1.76-2.24$ & $1.84 \pm 0.06^{\mathrm{b}}$ & $1.76-1.97$ \\
\hline$\Sigma \mathrm{OCFA}^{3}$ & $2.50 \pm 0.45$ & $2.18-2.57$ & $2.21 \pm 0.04$ & $2.15-2.27$ \\
\hline$\Sigma \mathrm{SFA}^{4}$ & $58.61 \pm 1.12^{b}$ & $57.24-60.41$ & $62.30 \pm 0.84^{a}$ & $61.40-63.99$ \\
\hline$\Sigma$ MUFA $^{5}$ & $27.25 \pm 0.60^{a}$ & $26.32-28.62$ & $25.75 \pm 0.50^{b}$ & $25.19-26.48$ \\
\hline ¿PUFA 6 & $3.68 \pm 0.60^{\mathrm{a}}$ & $2.83-4.51$ & $2.74 \pm 0.14^{b}$ & $2.61-3.00$ \\
\hline$n-3$ & $0.53 \pm 0.13^{a}$ & $0.31-0.66$ & $0.35 \pm 0.05^{b}$ & $0.31-0.42$ \\
\hline$n-6$ & $1.52 \pm 0.19$ & $1.28-1.78$ & $1.54 \pm 0.14$ & $1.39-1.86$ \\
\hline$n-6 / n-3$ & $3.04 \pm 0.81^{\mathrm{b}}$ & $2.42-4.74$ & $4.52 \pm 0.99^{a}$ & $3.56-5.64$ \\
\hline UFA $^{7}$ & $30.93 \pm 0.94^{a}$ & $29.29-32.44$ & $28.50 \pm 0.47^{b}$ & $27.75-29.16$ \\
\hline DFA $^{8}$ & $40.89 \pm 1.38^{a}$ & $38.49-42.58$ & $38.14 \pm 0.91^{b}$ & $36.86-39.42$ \\
\hline OFA $^{9}$ & $48.66 \pm 1.62^{b}$ & $46.68-51.21$ & $52.60 \pm 1.15^{\mathrm{a}}$ & $51.14-55.10$ \\
\hline $\mathrm{AI}^{10}$ & $2.01 \pm 0.07^{\mathrm{b}}$ & $1.85-2.12$ & $3.06 \pm 0.05^{\mathrm{a}}$ & $3.00-3.17$ \\
\hline $\mathrm{TI}^{11}$ & $1.99 \pm 0.11^{b}$ & $1.83-2.14$ & $3.79 \pm 0.06^{\mathrm{a}}$ & $3.71-3.87$ \\
\hline $\mathrm{H} / \mathrm{H}^{12}$ & $0.49 \pm 0.03^{a}$ & $0.45-0.53$ & $0.43 \pm 0.01^{b}$ & $0.42-0.45$ \\
\hline
\end{tabular}

n-number of samples; Mean-mean value; SD—standard deviation; Min-minimum value; Max-maximum value; $a, b$-values denoted in rows by different letters indicate statistically significant differences $(p<0.05) ;{ }^{1} \Sigma$ SCFA: sum of short-chain fatty acids (C4:0-C10:0); ${ }^{2} \Sigma$ BCFA-all branched-chain fatty acids; ${ }^{3} \Sigma$ OCFA—all odd-chain fatty acids; ${ }^{4}$ SFA-all saturated fatty acids (without SCFA); ${ }^{5} \Sigma$ MUFA—sum of monounsaturated fatty acids; ${ }^{6} \Sigma$ PUFA—sum of polyunsaturated fatty acids; ${ }^{7}$ UFA-sum of unsaturated fatty acids ( MUFA $+\Sigma$ PUFA); 8 DFA-hypocholesterolemic fatty acids ( $\Sigma$ UFA + C18:0);

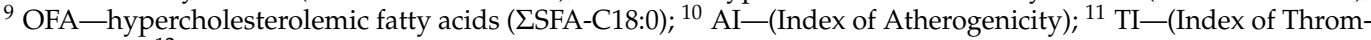
bogenicity); ${ }^{12} \mathrm{H} / \mathrm{H}-$ (hypocholesterolaemic/hypercholesterolaemic ratio).

In the presented study, $n-3$ PUFA content was significantly higher $(p<0.05)$ in summer cheeses than winter cheeses, whereas the content of $n-6$ PUFA was at similar level (Table 4). The values of lipid quality indexes varied between summer and winter cheeses (Table 4). Summer cheeses contained significantly more $(p<0.05)$ desirable hypocholesterolemic fatty acids (DFAs) and significantly less $(p<0.05)$ hypercholesterolemic fatty acids (OFA). Furthermore, the AI and TI indexes were significantly higher $(p<0.05)$ in winter cheeses. The AI and TI indexes are believed to have an impact on the risk of cardiovascular diseases [11]. The higher values of these indices higher risk of certain diseases. Dairy products with lower AI values can reduce levels of total cholesterol and LDL-cholesterol in human plasma [66]. A significantly higher $(p<0.05) \mathrm{H} / \mathrm{H}$ content was found in summer cheeses than in winter cheeses. Moreover, summer cheeses had more favorable ratio of $n-6$ to $n-3$ acids (3.04) compared to winter cheeses (4.52), which may indicate better health-promoting properties of summer cheeses. Proportions of fatty acids specific groups in dairy products are of special importance from a nutritional perspective. Excessive amounts of $n-6$ PUFA and very high $n-6 / n-3$ ratio, which can be typically found in today's Western diets, promote the pathogenesis of many diseases, whereas increased levels of $n-3$ PUFA (a low $n-6 / n-3$ ratio) exert suppressive effects [83-85]. Similar results were obtained by Hirigoyen et al. for the $n-6 / n-3$ ratio in the cheeses [86]. The authors demonstrated that this ratio in "Colonia" cheeses produced from cow's milk in spring was 4.47 and 3.29 in cheeses produced in autumn.

\subsection{The Content of CLA and Trans C18:1 and Trans C18:2 Fatty Acids in Cheese}

The content of cis9trans11 C18:2 (CLA) and total content of C18:1 and C18:2 trans isomers in summer and winter cheeses are presented on Figure 2. The conducted analyses indicated that summer cheeses had significantly higher $(p<0.05)$ content of CLA than winter cheeses $(0.88 \%$ and $0.44 \%$, respectively). 


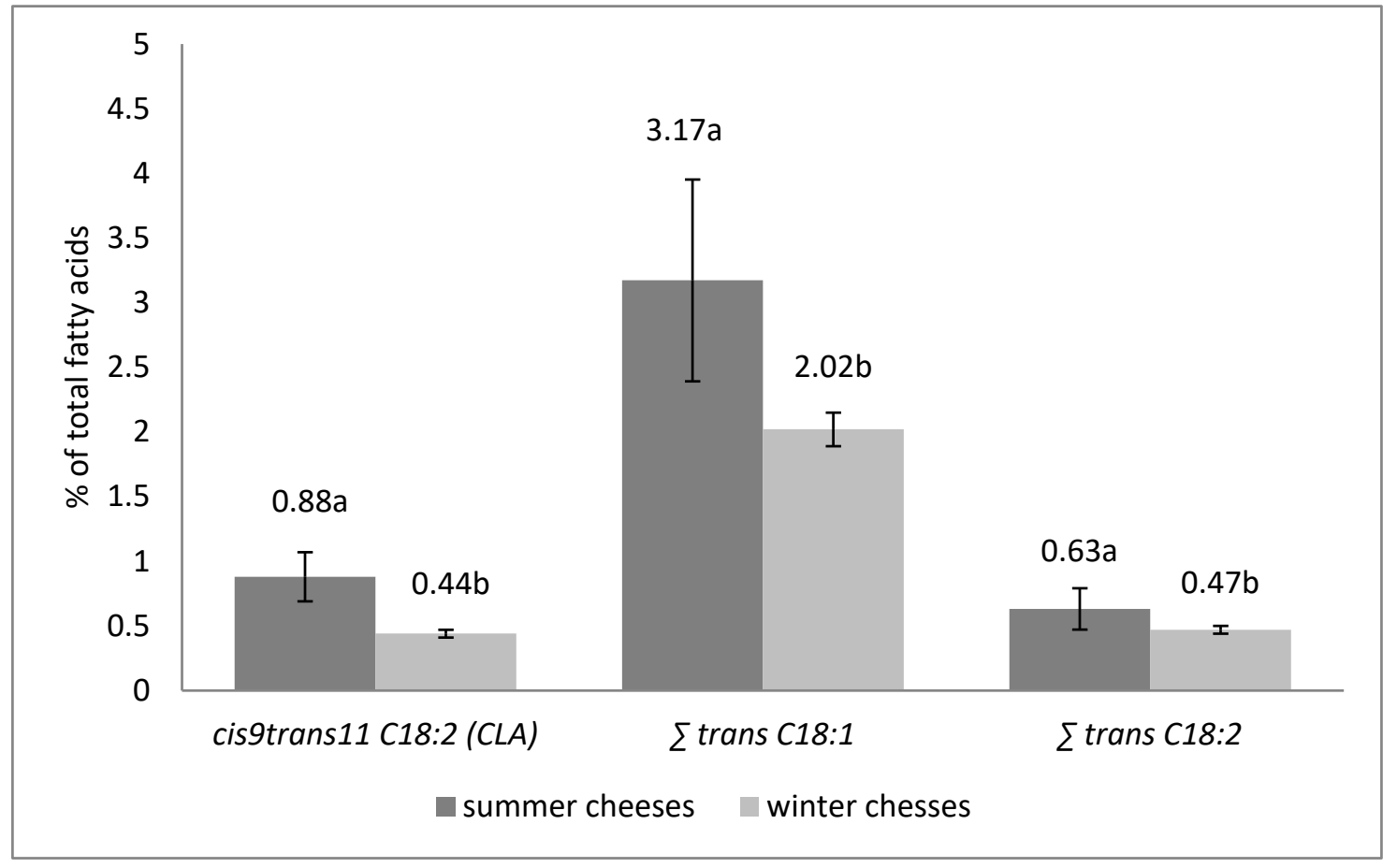

Figure 2. The content of cis9trans11 C18:2 (CLA) and total C18:1 and C18:2 trans isomers (\% of total fatty acids) in summer and winter cheeses made from cow's milk. Etrans C18:1—sum of trans isomers of C18:1, $\sum$ sum of trans C18:2 without $c 9 t 11$ C18:2, a,b-statistically significant differences $(p<0.05)$.

Dairy products, such as milk, cheese, and yogurt are the principal natural sources of CLA in the human diet. The term conjugated linoleic acid (CLA) refers to a group of positional and geometric isomers of linoleic acid characterized by the presence of two conjugated double bonds. The main isomer in dairy products is rumenic acid, cis 9 trans 11 CLA, which represents 75 to over $90 \%$ of total CLA in milk fat [87]. CLA is an intermediate in the biohydrogenation of linoleic acid in the rumen, but its main source is endogenous synthesis from trans $11 \mathrm{C} 18: 1$ acid by $\Delta 9$-desaturase [88]. According to Żegarska et al. [89], the content of CLA in milk fat ranged from $0.32 \%$ to $0.52 \%$ in the winter season and from $1.06 \%$ to $1.76 \%$ in the pasture period. Several studies have also demonstrated a large variation of CLA content in cheese. Fritsche and Steinhart [90] analyzed German cheese made from cow's milk, and found that CLA content in total fatty acid composition varied from $0.40 \%$ to $1.70 \%$. Donmez et al. [91] indicated that CLA content in fat from Turkish cheeses ranged from 0.44 to $1.04 \mathrm{~g} / 100 \mathrm{~g}$. According to Grega et al. [92], CLA content in commercial cheeses ranged from $0.20 \%$ to $0.95 \%$ in the winter season and from $0.61 \%$ to $1.57 \%$ in the summer season. Żegarska et al. [89] observed that in hard commercial cheeses, purchased in February and March, CLA content in total fatty acid composition ranged from $0.48 \%$ to $1.68 \%$, while cheeses bought in October and November had from $0.97 \%$ to $1.46 \%$. In commercial cheeses bought in the period from November to December analyzed by Paszczyk and Łuczyńska [82], the CLA content varied from $0.46 \%$ to $0.85 \%$ of total fatty acids.

In the group of trans $\mathrm{C} 18: 1$ isomers, the trans 11 isomer is the dominant one; it accounts for about $40-50 \%$ in total C18:1 trans fatty acids [93]. The animal feeding system can influence the content of this isomer in milk fat [94,95]. In the presented study, the total content of C18:1 and C18:2 trans isomers in summer cheeses was significantly higher $(p<0.05)$ compared to winter cheeses (Figure 2). Obtained results are in consistence with Żegarska et al. [38], who demonstrated that trans C18:1 isomers ranged from 3.57\% to 5.37\%, and from $1.26 \%$ to $1.84 \%$ in summer and winter milk, respectively. Moreover, research conducted on commercial cheeses by Żegarska et al. [89], purchased in February and March, also demonstrated that total content of trans C18:1 isomers ranged from $1.65 \%$ to $4.42 \%$ in 
total fatty acids composition. Whereas, the proportion of trans C18:1 isomers in cheeses purchase from October and November varied from $4.14 \%$ to $4.69 \%$. Authors also showed that content of trans C18:2 isomers in cheeses purchased from February to March ranged from $0.44 \%$ to $1.17 \%$, and from $0.96 \%$ to $1.11 \%$ in cheeses bought from October to November, which is consistent with the presented study. In addition, Paszczyk and Łuczyńska [82] indicated that total content of C18:1 and C18:2 trans isomers, in Polish cheeses made from cow's milk (purchased from September to December), ranged from $2.58 \%$ to $3.27 \%$ and trans $\mathrm{C} 18: 2$ ranged from $0.50 \%$ to $0.75 \%$ in total fatty acids composition.

\section{Conclusions}

Interest in cheeses, and the demands of increasingly aware consumers mean that new varieties of cheese are constantly being supplied to the market. Consumers are paying more and more attention to the composition of the food they eat, while at the same time looking for products that are as natural as possible. Animal feeding influences the quality and chemical composition of milk, and thus the quality and composition of cheeses. Therefore the evaluation of cheese properties is becoming more and more important. According to the obtained results, the chemical composition, content of fatty acids, CLA, other trans isomers, and lipid quality indices varied in summer and winter cheeses. Winter cheeses were characterized as a better source of protein than summer cheeses and might be a better choice, meeting daily protein requirements of different population groups.

Author Contributions: Conceptualization, B.P.; methodology, B.P.; validation, B.P. and M.P.-Ś.; formal analysis, B.P.; investigation, B.P.; data curation, B.P.; writing-original draft preparation, B.P. and M.P.-Ś; writing—review and editing, B.P., M.P.-Ś., B.P. and M.P.-Ś.; supervision, A.E.Z.-S. All authors have read and agreed to the published version of the manuscript.

Funding: Project financially supported by the Minister of Education and Science under the program entitled "Regional Initiative of Excellence" for the years 2019-2022, Project No. 010/RID/2018/19, amount of funding 12.000.000 PLN.

Institutional Review Board Statement: Not applicable.

Informed Consent Statement: Not applicable.

Data Availability Statement: Data is contained within the article.

Conflicts of Interest: The authors declare no conflict of interest.

\section{References}

1. Piekut, M. Production and consumption of cheese in Poland. Dairy Rev. 2012, 7, 36-38.

2. Szajner, P. Polish dairy products supply—Demand. Food Ind. 2013, 4, 8-12.

3. Polish Federation of Cattle Breeders and Milk Producers. Milk Market Report I/2021. 2021. Available online: https:/ /pfhb.pl/ fileadmin/aktualnosci/2021/rynek_mleka/Raport_Rynek_mleka_I2021_r.pdf (accessed on 29 June 2021).

4. Walther, B.; Schmid, A.; Sieber, R.; Wehrmüller, K. Cheese in nutrition and health. Dairy Sci. Technol. 2008, 88, 389-405. [CrossRef]

5. Jensen, R.G. The composition of bovine milk lipids: January 1995 to December 2000. J. Dairy Sci. 2002, 85, 295-350. [CrossRef]

6. Månsson, H.L. Fatty acids in bovine milk fat. Food Nutr. Res. 2008, 52, 1821. [CrossRef] [PubMed]

7. Simopoulos, A.P. The importance of the ratio of omega-6/omega-3 essential fatty acids. Biomed. Pharm. 2002, 56, 365-379. [CrossRef]

8. Bernard, L.; Bonnet, M.; Delavaud, C.; Delosiére, M.; Ferlay, A.; Fougére, H.; Graulet, B. Milk fat globule in ruminant: Major and minor compounds, nutritional regulation and differences among species. Eur. J. Lipid Sci. Technol. 2018, 102, 1-27. [CrossRef]

9. Parodi, P.W. Has the association between saturated fatty acids, serum cholesterol and coronary heart disease been over emphasized? Int. Dairy J. 2009, 19, 345-361. [CrossRef]

10. Haug, A.; Høstmark, A.T.; Harstad, O.M. Bovine milk in human nutrition-A review. Lipids Health Dis. 2007, 6, 1-16. [CrossRef]

11. Ulbricht, T.L.V.; Southgate, D.A.T. Coronary heart disease: Seven dietary factors. Lancet 1991, 338, 985-992. [CrossRef]

12. Wongtangtintharn, S.; Oku, H.; Iwasaki, H.; Toda, T. Effect of branched-chain fatty acids on fatty acid biosynthesis of human breast cancer cells. J. Nutr. Sci. Vitaminol. 2004, 50, 137-143. [CrossRef]

13. Adamska, A.; Rutkowska, J. Odd- and branched-chain fatty acids in milk fat-Characteristic and health properties. Postepy Hig. Med. Dosw. 2014, 68, 998-1007. [CrossRef] [PubMed] 
14. Taormina, V.M.; Unger, A.L.; Schiksnis, M.R.; Torres-Gonzalez, M.; Kraft, J. Branched-Chain fatty acids-An underexplored class of dairy-derived fatty acids. Nutrients 2020, 12, 2875. [CrossRef] [PubMed]

15. Arnould, V.M.-R.; Soyeurt, H. Genetic variability of milk fatty acids. J. Appl. Genet. 2009, 50, 29-39. [CrossRef]

16. Summer, A.; Formaggioni, P.; Franceschi, P.; Frangia, F.D.; Righi, F.; Malacarne, M. Cheese as functionalfood: The example of parmigiano reggiano and grana padano. Food Technol. Biotechnol. 2017, 55, 277-289. [CrossRef] [PubMed]

17. Lim, J.-N.; Oh, J.-J.; Wang, T.; Lee, J.-S.; Kim, S.-H.; Kim, Y.-H.; Lee, H.-G. Trans-11 $18: 1$ vaccenic acid (TVA) has a direct anti-carcinogenic effect on MCF-7 human mammary adenocarcinoma cells. Nutrients 2014, 6, 627-636. [CrossRef]

18. Akalln, A.S.; Tokusoglu, Ö. A potential Anticarcinogenic Agent: Conjugated linoleic acid (CLA). Pak. J. Nutr. 2003, 2, 109-110. [CrossRef]

19. Parodi, P.W. Anti-cancer agents in milkfat. Aust. J. Dairy Technol. 2003, 58, 114-118.

20. Aydin, R. Conjugated linoleic acid: Structure, sources and biological properties. Turk. J. Vet. Anim. Sci. 2005, 29, 189-195.

21. Park, Y. Conjugated linoleic acid (CLA): Good or bad trans fat? J. Food Compos. Anal. 2009, 22, S4-S12. [CrossRef]

22. Kee, J.-I.; Ganesan, P.; Kwak, H.-S. Bioactive conjugated linoleic acid (CLA) in milk. Korean J. Food Sci. Anim. Resour. 2010, 30, 879-885. [CrossRef]

23. Williams, C.M. Dietary fatty acids and human health. Ann. Zootech. 2000, 49, 165-180. [CrossRef]

24. Gómez-Cortés, P.; Juárez, M.; Angel de la Fuente, M. Milk fat acids and potential health benefits: An update vision. Trends Food Sci. Technol. 2018, 81, 1-9. [CrossRef]

25. Czajkowska, A.; Szponar, B. Short chain fatty acids (SCFA), the products of gut bacteria metabolism and their role in the host. Postęp. Hig. Med. Doswiadczalnej. 2018, 72, 131-142. [CrossRef]

26. Soyeurt, H.; Dardenne, P.; Gillon, A.; Croquet, C.; Vanderick, S.; Mayeres, P.; Bertozzi, C.; Gengler, N. Variation in fatty acid contents of milk and milk fat within and across breeds. J. Dairy Sci. 2006, 89, 4858-4865. [CrossRef]

27. Capuano, E.; Gravink, R.; Boerrigter-Eenling, R.; van Ruth, S.M. Fatty acid and triglycerides profiling of retail organic, conventional and pasture milk: Implications for health and authenticity. Int. Dairy J. 2015, 42, 58-63. [CrossRef]

28. Chilliard, Y.; Ferlay, A.; Mansbridge, R.M.; Doreau, M. Ruminant milk fat plasticity: Nutritional control of saturated, polyunsaturated, trans and conjugated fatty acids. Ann. Zootechnol. 2000, 49, 181-205. [CrossRef]

29. Hanuš, O.; Krí̌̌ová, L.; Samková, E.; Špička, J.; Kučera, J.; Klimešová, M.; Roubal, P.; Jedelská, R. The effect of cattle bread, season and type of diet on the fatty acid profile of raw milk. Arch. Anim. Breed. 2016, 59, 373-380. [CrossRef]

30. Kelsey, J.A.; Corl, B.A.; Collier, R.J.; Bauman, D.E. The effect of breed, parity and stage of lactation on conjugated linoleic acid (CLA) in milk fat from dairy cows. J. Dairy Sci. 2003, 86, 2588-2597. [CrossRef]

31. Ellis, K.A.; Innocent, G.; Grove-White, D.; Cripps, P.; Mclean, W.G.; Howard, C.V.; Mihm, M. Comparing the fatty acid composition of organic and conventional milk. J. Dairy Sc. 2006, 89, 1938-1950. [CrossRef]

32. Zunong, M.; Hanada, M.; Aibibula, Y.; Okamato, M.; Tanaka, K. Variations in conjugated linoleic acid concentrations in cow's milk, depending on feeding systems in different seasons. Asian Aust. J. Anim. Sci. 2008, 21, 1466-1472. [CrossRef]

33. Kuczyńska, B.; Nałęcz-Tarwacka, T.; Puppel, K.; Gołębiewski, M.; Grodzki, H.; Slósarz, J. The content of bioactive components in milk depending on cow feeding model in certified ecological farms. J. Res. Appl. Agric. Eng. 2011, 56, 7-13.

34. Lipiński, K.; Stasiewicz, M.; Rafałowski, R.; Kaliniewicz, J.; Purwin, C. Effect of milk production season on profile of fatty acids in milk fat. Żywność Nauka Technol. Jakość 2012, 1, 72-80. [CrossRef]

35. Frelich, J.; Šlachta, M.; Hanuš, O.; Špička, J.; Samková, E.; Węglarz, A.; Zapletal, P. Seasonal variation in fatty acid composition of cow milk in relation to the feeding system. Anim. Sci. Pap. Rep. 2012, 30, 219-229.

36. Radkowska, I. Effect of housing system and diet on the fatty acid, vitamin and macronutrient content of milk from holstein-friesian cows. Rocz. Nauk. Zoot. 2013, 40, 171-182.

37. Żegarska, Z.; Paszczyk, B.; Borejszo, Z. Trans fatty acids in milk fat. Pol. J. Food Nutr. Sci. 1996, 5/46, 89-97.

38. Żegarska, Z.; Paszczyk, B.; Rafałowski, R.; Borejszo, Z. Annual changes in the content of unsaturated fatty acids with 18 carbon atoms, including cis9, trans11 C18:2 (CLA) acid, in milk fat. Pol. J. Nutr. Sci. 2006, 15/56, 409-414.

39. Chilliard, Y.; Ferlay, A. Dietary lipids and forages interactions on cow and goat milk fatty acid composition and sensory properties. Reprod. Nutr. Dev. 2004, 44, 467-492. [CrossRef]

40. Uzun, P.; Masucci, F.; Serrapica, F.; Napolitano, F.; Braghieri, A.; Romano, R.; Manzo, N.; Esposito, G.; Di Francia, A. The inclusion of fresh forage in the lactating buffalo diet affects fatty acid and sensory profile of mozzarella cheese. J. Dairy Sci. 2018, 101, 6752-6761. [CrossRef]

41. Lucas, A.; Rock, E.; Chamba, J.-F.; Verdier-Metz, I.; Brachet, P.; Coulon, J.-B. Respective effects of milk composition and the cheese-making process on cheese compositional variability in components of nutritional interest. Lait 2006, 86, 21-41. [CrossRef]

42. Bittante, G.; Cipolat-Gotet, C.; Malchiodi, F.; Sturaro, E.; Tagliapietra, F.; Schiavon, S.; Cecchinato, A. Effect of dairy farming system, herd, season, parity, and days in milk on modeling of the coagulation, curd firming, and syneresis of bovine milk. J. Dairy Sci. 2014, 98, 2759-2774. [CrossRef]

43. Franceschi, P.; Malacarne, M.; Formaggioni, P.; Faccia, M.; Summer, A. Quantification of the Effect of the Cattle Breed on Milk Cheese Yield: Comparison between Italian Brown Swiss and Italian Friesian. Animals 2020, 10, 1331. [CrossRef]

44. Bojanić Rašović, M.; Nikolić, N.; Martinović, A.; Katić, V.; Rašović, R.; Walcer, M.; Domig, K. Correlation between protein to fat ratio of milk and chemical parameters and the yield of semi-hard cheese. Biotechnol. Anim. Husb. 2013, 29, 145-159. [CrossRef] 
45. Bland, J.H.; Grandison, A.S.; Fagan, C.C. The effect of blending Jersey and Holstein- Friesian milk on composition and coagulation properties. Int. J. Dairy Technol. 2015, 68, 3-6. [CrossRef]

46. Taboada, N.; Van Nieuwenhove, C.; Alzogaray, S.L.; Medina, R. Influence of autochthonous cultures on fatty acid composition, esterase activity and sensory profile of Argentinean goat cheeses. J. Food Compos. Anal. 2015, 40, 86-94. [CrossRef]

47. Manuelian, C.L.; Currò, S.; Penasa, M.; Cassandro, M.; De Marchi, M. Characterization of major and trace minerals, fatty acid composition, and cholesterol content of protected designation of origin cheeses. J. Dairy Sci. 2017, 100, 3384-3395. [CrossRef]

48. Lin, T.Y. Conjugated linoleic acid concentration as affected by lactic cultures and additives. Food Chem. 2000, 69, 27-31. [CrossRef]

49. Murtaza, M.A.; Huma, N.; Hayat, Z.; Murtaza, M.S.; Meraj, A. Cheddar cheese from cow milk with elevated conjugated linoleic acid levels. J. Food Nutr. Res. 2014, 2, 506-509. [CrossRef]

50. Kim, J.H.; Kwon, O.J.; Choi, N.J.; Oh, S.J.; Jeong, H.Y.; Song, M.K.; Jeong, I.; Kim, Y.J. Variations in conjugated linoleic acid (CLA) content of processed cheese by lactation time, feeding regimen, and ripening. J. Agric. Food Chem. 2009, 57, 3235-3239. [CrossRef] [PubMed]

51. Prandini, A.; SigoLo, S.; Piva, G. A comparative study of fatty acid composition and CLA concentration in commercial cheeses. J. Food Compos. Anal. 2011, 24, 55-61. [CrossRef]

52. Sieber, R.; Collomb, M.; Aeschlimann, A.; Jelen, P.; Eyer, H. Impact of microbial cultures on conjugated linoleic acid in dairy products-A review. Int. Dairy J. 2004, 14, 1-15. [CrossRef]

53. Kim, Y.J.; Liu, R.H. Increase of conjugated linoleic acid content in milk by fermentation with lactic acid bacteria. J. Food Sci. 2002, 67, 1731-1737. [CrossRef]

54. Rutkowska, J.; Sadowska, A.; Tabaszewska, M.; Stołyhwo, A. Fatty acid composition of hard cheeses from north, eastern and central region of Poland. Bromatol. Chem. Toksykol. 2009, 42, 263-269.

55. Zeppa, G.; Giordano, M.; Gerbi, V.; Arlorio, M. Fatty acid composition of Piedmont “Ossolano" cheese. Lait 2003, 82, 167-173 [CrossRef]

56. Serrapica, F.; Masucci, F.; Di Francia, A.; Napolitano, F.; Braghieri, A.; Esposito, G.; Romano, R. Seasonal variation of chemical composition, fatty acid profile, and sensory properties of a Mountain Pecorino Cheese. Foods 2020, 9, 1091. [CrossRef] [PubMed]

57. Wangin, J. Manufacture of Rennet Ripening Cheeses; LACPRES Publishing House: Warsaw, Poland, 1989.

58. Christie, W.W. (Ed.) The isolation of lipids from tissues. Recommended Procedures. Chloroform-methanol (2:1,v/v) extraction and "Folch" wash. In Lipid Analysis. Isolation, Separation, Identification and Structural Analysis of Lipids; Pergamon Press: Oxford, UK; New York, NY, USA; Toronto, ON, Canada; Tokyo, Japan; Sydney, Australia; Braunschweig, Germany, 1973 ; pp. 39-40.

59. International Organization for Standardization. ISO 15884:2002 (IDF 182:2002). Milkfat: Preparation of Fatty Acid Methyl Esters; International Organization for Standardization: Geneva, Switzerland, 2002.

60. Roach, J.A.G.; Mossoba, M.M.; Yurawecz, M.P.; Kramer, J.K.G. Chromatographic separation and identification of conjugated linoleic acid isomers. Anal. Chim. Acta 2002, 465, 207-226. [CrossRef]

61. Kramer, J.K.G.; Cruz-Hermantez, C.; Deng, Z.; Zhou, J.; Jahreis, G.; Dugan, M.E.R. Analysis of conjugated linoleic acid and trans 18:1 isomers in syntetic and animal products. Am. J. Clin. Nutr. 2004, 79, 1137S-1145S. [CrossRef]

62. LeDoux, M.; Chardigny, J.-M.; Darbois, M.; Soustre, Y.; Sébédio, J.-L.; Laloux, L. Fatty acid composition of French butters, with special emphasis on conjugated linoleic acid (CLA) isomers. J. Food Compos. Anal. 2005, 18, 409-425. [CrossRef]

63. Contarini, G.; Povolo, M.; Pelizzola, V.; Monti, L.; Lercker, G. Interlaboratory evaluation of milk fatty acid composition by using different GC operating conditions. J. Food Compos. Anal. 2013, 32, 131-140. [CrossRef]

64. Osmari, E.K.; Cecato, U.; Macedo, F.A.F.; Souza, N.E. Nutritional quality indices of milk fat from goats on diets supplemented with different roughages. Small Rumin. Res. 2011, 98, 128-132. [CrossRef]

65. Medeiros, E.; Queiroga, R.; Oliveira, M.; Medeiros, A.; Sabedot, M.; Bomfim, M.; Madruga, M. Fatty Acid Profile of Cheese from Dairy Goats Fed a Diet Enriched with Castor, Sesame and Faveleira Vegetable Oils. Molecules 2014, 19, 992-1003. [CrossRef]

66. Ivanova, A.; Hadzhinikolova, L. Evaluation of nutritional quality of common carp (Cyprinus carpio L.) lipidsthrough fatty acid ratios and lipid indices. Bulg. J. Agric. Sci. 2015, 21, 180-185.

67. Jarosz, M.; Rychlik, E.; Cichocka, A.; Białkowska, M. Nutrition Standards for the Polish Population; Jarosz, M., Ed.; Institute of Food and Nutrition: Warsaw, Poland, 2020; pp. 21-39.

68. CSO. Situation of Households in 2019 in the Light of the Results of the Household Budget Survey; CSO: Bergerac, France, 2019.

69. Statsoft. STATISTIC, Version 13.1 Software; Statsoft: Kraków, Poland, 2007.

70. De Marchi, M.; Bittante, G.; Dal Zotto, R.; Dalvit, C.; Cassandro, M. Effect of Holstein Friesian and Brown Swiss breeds on quality of milk and cheese. J. Dairy Sci. 2008, 91, 4092-4102. [CrossRef] [PubMed]

71. Formaggioni, P.; Summer, A.; Malacarne, M.; Franceschi, P.; Mucchetti, G. Italian and Italian-style hard cooked cheeses: Predictive formulas for Parmigiano-Reggiano 24-h cheese yield. Int. Dairy J. 2015, 51, 52-58. [CrossRef]

72. Uzun, P.; Serrapica, F.; Masucci, F.; Assunta, B.C.M.; Yildiz, H.; Grasso, F.; Di Francia, A. Diversity of traditional Caciocavallo cheeses produced in Italy. Int. J. Dairy Technol. 2019, 73, 234-243. [CrossRef]

73. Esposito, G.; Masucci, F.; Napolitano, F.; Braghieri, A.; Romano, R.; Manzo, N.; Di Francia, A. Fatty acid and sensory profiles of Caciocavallo cheese as affected by management system. J. Dairy Sci. 2014, 97, 1918-1928. [CrossRef]

74. Lešić, T.; Pleadin, J.; Krešić, G.; Vahčić, N.; Markov, K.; Vrdoljak, M.; Frece, J. Chemical and fatty acid composition of cow and sheep milk cheeses in a lamb skin sack. J. Food Compos. Anal. 2016, 46, 70-77. [CrossRef] 
75. EFSA Panel on Dietetic Products, Nutrition and Allergies (NDA). Scientifc opinion on Dietary Reference Values for protein. EFSA J. 2012, 10, 2557. [CrossRef]

76. EFSA (European Food Safety Authority). Dietary Reference Values for Nutrients; Summary Report, EFSA Supporting Publication; EFSA (European Food Safety Authority): Parma, Italy, 2017; p. e15121. [CrossRef]

77. Food and Agriculture Organization of the United Nations/World Health Organization/United Nations University (FAO/WHO/UNU). Protein and Amino Acids Requirements in Human Nutrition; Report of a Joint FAO/WHO/UNU Expert Consultation; WHO Technical Report Series 935; WHO: Geneva, Switzerland, 2007; p. 2011.

78. Arnett Tymoczko, J.L.; Berg, J.M.; Stryer, L. Biochemistry; Short Course; Scientific Publishers PWN: Warsaw, Poland, 2013; pp. 193-206.

79. Maldonado, G.E.; Gallego-Narbón, A.; Vaquero, M.P. Are vegetarian diets nutritionally adequate? A revision of the scientific evidence. Nutr. Hosp. 2019, 36, 950-961. [CrossRef]

80. Rocha, J.P.; Laster, J.; Parag, B.; Shah, N.U. Multiple Health Benefits and Minimal Risks Associated with Vegetarian Diets. Curr Nutr. Rep. 2019, 8, 374-381. [CrossRef] [PubMed]

81. Prandini, A.; Sigolo, S.; Tansini, G.; Brogna, N.; Piva, G. Different level of conjugated linolei acid (CLA) in dairy products from Italy. J. Food Compos. Anal. 2007, 20, 472-479. [CrossRef]

82. Paszczyk, B.; Łuczyńska, J. The comparison of fatty acids composition and lipid quality indices in hard cow, sheep and goat cheeses. Foods 2020, 9, 1667. [CrossRef] [PubMed]

83. Wijendran, V.; Hayes, K.C. Dietary $n-6$ and n-3 fatty acid balance and cardiovascular health. Annu. Rev. Nutr. 2004, 24, 597-615. [CrossRef]

84. Simopoulos, A.P. The importance of the omega-6/omega-3 fatty acid ratio in cardiovascular disease and other chronic diseases Exp. Biol. Med. 2008, 233, 674-688. [CrossRef]

85. Tóth, T.; Mwau, P.J.; Bázár, G.; Andrássy-Baka, G.; Hingyi, H.; Csavajda, E.; Varga, L. Effect of feed supplementation based on extruded linseed meal and fish oil on composition and sensory properties of raw milk and ultra-high temperature treated milk. Int. Dairy J. 2019, 99, 104552. [CrossRef]

86. Hirigoyen, D.; de los Santos, R.; Calvo, M.F.; Gonzales-Revello, A.; Constantin, M. Chemical composition and seasonal changes in the fatty acid profile of Uruguayan “Colonia" Cheeses. Grasas Aceites 2018, 69, e254. [CrossRef]

87. Gutiérrez, L.F. Conjugated linoleic acid in milk and fermented milks: Variation and effects of the technological processes. VITAE Rev. Fac. Cienc. Farm. Aliment. 2016, 23, 134-145. [CrossRef]

88. Griinari, J.M.; Corl, B.A.; Lacy, S.H.; Chouinard, P.Y.; Nurmela, K.V.V.; Bauman, D.E. Conjugated linoleic acid is synthesized endogenously in lactating dairy cows by $\Delta$ 9-desaturase. J. Nutr. 2000, 130, 2285-2291. [CrossRef] [PubMed]

89. Żegarska, Z.; Paszczyk, B.; Borejszo, Z. Conjugated linoleic acid (CLA) and trans C18:1 and C18:2 isomers in fat of some commercial dairy products. Pol. J. Natur. Sci. 2008, 23, 248-256. [CrossRef]

90. Fritsche, J.; Steinhart, H. Amounts of conjugated linoleic acid (CLA) in German foods and evaluation of daily intake. Z. Fur Lebensm. -Unters. Und -Forsch. A 1998, 206, 77-82. [CrossRef]

91. Donmez, M.; Seckin, A.K.; Sagdic, O.; Simsek, B. Chemical characteristics, fatty acid compositions, conjugated linoleic acid contents and cholesterol levels of same traditional Turkish cheeses. Int. J. Food Sci. Nutr. 2005, 56, 157-163. [CrossRef]

92. Grega, T.; Sady, M.; Najgebauer, D.; Domagała, J.; Pustkowiak, H.; Faber, B. Seasonal changes in the level of conjugated linoleic acid (CLA) in ripened cheeses. Biotechnol. Anim. Husb. 2005, 21, 251-253. [CrossRef]

93. Shingfield, K.J.; Chilliard, Y.; Toivonen, P.; Kairenius, P.; Givens, D.I. Trans fatty acids and bioactive lipids in ruminant milk. Adv. Exp. Med. Biol. 2008, 606, 3-65. [CrossRef] [PubMed]

94. Dhiman, T.R.; Nam, S.-H.; Ure, M.L. Factors affecting conjugated linoleic acid content in milk and meat. Crit. Rev. Food Sci. Nutr. 2005, 45, 463-482. [CrossRef] [PubMed]

95. Lock, A.L.; Parodi, P.W.; Bauman, D.E. The biology of trans fatty acids: Implications for human health and the dairy industry. Aust. J. Dairy Technol. 2005, 60, 134-142. 